\title{
Analysis of Economic Crimes in the Digital Age
}

\author{
Spector L.A.* Zhmurko R.D. \\ Institute of Service Sector and Entrepreneurship of the Don State Technical University in Shakhty \\ *Corresponding author: e-mail: Shpigunova96@mail.ru
}

\begin{abstract}
This paper discusses the criminal responsibility for crimes in the field of economic activity, which is envisaged by the rules of Chapter 22 of the Criminal Code of the Russian Federation. The economic and political transformations taking place in Russia have determined the need to reform the entire legal system in general and criminal law in particular. The transition to new economic relations focused on the free development of a market economy, on free entrepreneurship, fair competition with the equality of all forms of ownership, created (as a by-product) the conditions for committing socially dangerous acts not previously known to criminal law. In an effort to implement the idea of "everything, which is not explicitly forbidden by law, is allowed," the state provided an opportunity for new business entities to act independently, without government intervention, which objectively created the conditions for abuse and fraudulent operations by dishonest business entities. These socially dangerous actions (manifestations of monopoly, unfair competition, deception of creditors, false bankruptcy, etc.) affected the interests of all economic entities, the state, and private entrepreneurs, and prevented the progressive development of new economic relations.
\end{abstract}

Keywords: economic crimes, criminal liability, monopoly, law, state

\section{INTRODUCTION}

The fundamental principles of legal regulation of new economic relations were laid down in Articles 8, 34, 35, and 36 of the Constitution of the Russian Federation [1]. Article 8 guarantees the participants in new economic relations the unity of the economic space, the free movement of goods, services, and financial resources, support for competition, freedom of economic activity in the conditions of equality of all forms of ownership. Articles 34, 35, 36 establish guarantees of the right of citizens to the free use of their abilities and property for entrepreneurial and other economic activities, which are not prohibited by law. But recognition of the freedom of economic relations does not mean a rejection of their state regulation, therefore, Part 2 of Article 34 of the Constitution recognized unacceptable activities aimed at monopolization and unfair competition. These constitutional principles formed the basis of new laws governing the economy in the field of civil, financial, and currency relations, they also allowed determining the circle of social relations that should be protected from criminal offenses by criminal law. Chapter 22 of the Criminal Code of 1996 in its original edition included 32 articles that legally defined the signs of 37 crimes. Later the chapter was supplemented by Articles 171.1, 174.1, and 185.1 [2]. The wording of Articles 169, 171, 174, 180, 183, 185, 188, and 189, as well as Articles 194, 198, and 199 of the Criminal Code were changed dramatically. Further work to improve legislation in the field of combating crimes in the field of economic activity was performed in 2003, as a result of which many of the provisions contained in Chapter 22 of the Criminal Code have undergone major changes, both in dispositions and in sanctions.

\section{METHODOLOGICAL RESEARCH}

According to statistics, the problem of combating crimes in the field of economic activity is an urgent problem in Russia. The extent of economic crime is evidenced by the size of the damage caused by it. If in 2002, 375.0 thousand economic crimes were registered and the damage caused by them amounted to 59.8 billion rubles; then in 2014, there were 376.8 thousand economic crimes with the damage of 75.2 billion rubles; in 2016, 402.4 thousand with the damage of 275.4 billion rubles; in 2018, 437.7 thousand with the damage of 1,399.6 billion rubles; and in 2019, 489.6 thousand with the damage 127.6 billion rubles. Chapter 22 of the Criminal Code provides for responsibility for crimes in the field of economic activity. The generic object of the crimes provided by Chapter 22 of the Criminal Code is social relations that make up the content of the economy as a whole. The specific object are relations regarding the production, distribution, exchange, and consumption of material values and services. Specific public relations, interests in various areas of economic 
activity, on which criminal attacks take place, are featured as the direct objects of the crimes of this chapter. Moreover, it should be noted that crimes of this category cause harm to additional direct objects. Studying the objective side of these crimes, it should be noted that the dispositions of many rules of law providing criminal responsibility for them are formulated by the legislator as blanket ones. In other words, for a correct understanding of the essence of the crime, it is required to study many statutory acts regulating the economic activity of various subjects. As for the criminal legal action directly as a sign of the objective side, then the components of crime from Chapter 22 of the Criminal Code give the expression both in the form of action (production or sale of fake credit or payment cards and other payment documents) and in the form of inaction (malicious evasion of paying off the indebtedness). The legislative structure of the components fo crimes that encroach on normal activities in the economic sphere is rather heterogeneous. Some of them are formulated as tangible (illegal business, false business), which are considered completed exclusively in the event of criminal consequences consisting in causal connection with a socially dangerous action, others, as formal, the completion of which is associated exclusively with the commission of the action (legalization of funds or other property acquired in an illegal way). The subjective side of the crimes committed in the field of economic activity is characterized by an exclusively intentional form of guilt. Moreover, the motive and purpose serve as a mandatory sign of some components. The subject of the crimes of the chapter under consideration is general or special if the sign characterizing it is directly indicated in the disposition of the article of the Special Part of the Criminal Code or follows from the meaning of the latter [3].

Depending on the direct object of the attack, the crimes committed in the field of economic activity can be divided into the following six groups. 1. Crimes encroaching on public relations, interests in the field of entrepreneurial activity: obstruction of legitimate entrepreneurial and other activities (Article 169 of the Criminal Code); registration of illegal transactions with land (Article 170 of the Criminal Code); illegal entrepreneurship (Article 171 of the Criminal Code); production, acquisition, storage, transportation, or sale of unlabelled goods and products (Article 171.1 of the Criminal Code); illegal banking activities (Article 172 of the Criminal Code); false business (Article 173 of the Criminal Code); legalization (laundering) of money and other property acquired by other persons in a criminal way (Article 174 of the Criminal Code); legalization (laundering) of money or other property acquired by a person as a result of a crime comnitted by it (Article 174.1 of the Criminal Code); acquisition or sale of property known to have been obtained in a criminal way (Article 175 of the Criminal Code); preventing, restricting, or eliminating competition (Article 178 of the Criminal Code); coercion to conclude a transaction or to refuse to conclude it (Article 179 of the Criminal Code); illegal use of a trademark (Article 180 of the Criminal Code); illegal receipt and disclosure of information constituting a commercial, tax, or banking secret (Article 183 of the Criminal Code); bribery of participants or organizers of professional sports competitions and spectacular commercial competitions (Article 184 of the Criminal Code). 2. Crimes encroaching on public relations, interests arising in the field of credit and finance: illegal obtaining of a loan (Article 176 of the Criminal Code); malicious evasion of redemption of accounts payable (Article 177 of the Criminal Code); abuse in the issue of securities (Article 185 of the Criminal Code); malicious evasion of providing the investor or regulatory body with information defined by the legislation of the Russian Federation on securities (Article 185.1 of the Criminal Code); the manufacture or sale of counterfeit money or securities (Article 186 of the Criminal Code); production or sale of fake credit or payment cards and other payment documents (Article 187 of the Criminal Code). 3. Crimes encroaching on the monopoly of state regulation in certain areas of public relations: violation of the rules for the manufacture and use of state assay marks (Article 181 of the Criminal Code); illegal trafficking of precious metals, natural precious stones, or pearls (Article 191 of the Criminal Code); violation of the rules for the transfer of precious metals and precious stones to the government circulation (Article 192 of the Criminal Code). 4. Crimes that encroach on public relations arising from the movement of values across the customs border: smuggling (Article 188 of the Criminal Code); illegal export of technologies, scientific and technical information and services used to create weapons of mass destruction, arms and military equipment (Article 189 of the Criminal Code); non-return to the territory of the Russian Federation of objects of the artistic, historical, and archaeological heritage of the peoples of the Russian Federation and foreign countries (Article 190 of the Criminal Code); non-return from abroad of funds in foreign currency (Article 193 of the Criminal Code). 5. Crimes encroaching on public relations, interests arising regarding the procedure for calculating and paying taxes and other payments: evasion of customs payments levied on a legal entity or an individual (Article 194 of the Criminal Code); evasion from taxes and/or fees levied on an individual (Article 198 of the Criminal Code); evasion of taxes and/or fees levied on a legal entity (Article 199 of the Criminal Code). 6. Crimes encroaching on public relations, interests ensuring the bankruptcy procedure: unlawful actions in bankruptcy (Article 195 of the Criminal Code); deliberate bankruptcy (Article 196 of the Criminal Code); fake bankruptcy (Article 197 of the Criminal Code). The crimes provided for by Chapter 22 of the Criminal Code of the Russian Federation are committed for the following reasons: selfish or other personal interest (Article 170, Article 181); selfish interest (Part 3 of Article 183); personal interests or interests of other persons (Article 196); personal interests (Art. 199.1), as well as pursue the following goals: sales (Articles 171.1, 186, and 187); obtaining loans, exemption from taxes, deriving other property benefits or covering 
prohibited activities (Article 173); giving a lawful form of possession, use, and disposal of money or other property (Article 174); for carrying out entrepreneurial or other economic activities (Article 174.1); exerting influence on the results of competitions or contests (Article 184); misleading creditors to obtain a deferment or installment of payments payable to creditors or discounts on debts, as well as evasion from taxes (Article 197).

\section{RESEARCH RESULTS}

An analysis of the provision of Chapter 22 of the Criminal Code of the Russian Federation showed that it does not have a unified system for constructing motives and goals, which causes certain difficulties in qualifying crimes. Ignoring the provisions formulated above leads to a violation of the consistency of provisions in the Criminal Code of the Russian Federation, to contradictions in their application. Based on this, it is thought that the legislator is required to make adjustments to Chapter 22 of the Criminal Code of the Russian Federation and use general technical and legal methods for constructing the subjective side of the crimes in the field of economic activity. Economic crimes are more often committed to the procedure established by the state and the rules for the legal movement of values across the customs border, Smuggling (Article 188 of the Criminal Code of the Russian Federation). The direct object is the stateestablished procedure and rules for the large-scale movement of goods and objects across the customs border, ensuring economic stability and security of Russia [4]. The objective side of smuggling is characterized by an action that involves the movement of goods in various forms; in addition to customs clearance, with concealment from customs clearance, with fraudulent use of documents or means of customs identification, associated with undeclared or untrue declaration. Qualified smuggling components are actions committed by an official using its official position or violence against a person exercising customs clearance. Particularly qualified smuggling components constitute its commission by an organized group. Illegal export or transfer of raw materials, materials, equipment, technologies, scientific and technical information, illegal performance of work (rendering of services) that can be used to create weapons of mass destruction, arms and military equipment (Article 189 of the Criminal Code of the Russian Federation). The direct object is the state interests of the Russian Federation when ensuring compliance with international obligations on the non-proliferation of weapons of mass destruction, arms and military equipment [10]. The subject of the crime is technology, scientific and technical information and services, raw materials, materials and equipment that can be used to create weapons of mass destruction, their delivery vehicles, arms and military equipment. Qualified components involve the commission of an action by a group of persons by prior conspiracy [9]. Specially qualified components provide for the following signs: the commission of an action by an organized group either in relation to raw materials, materials, equipment, technologies, scientific and technical information, works (services), which obviously can be used to create weapons of mass destruction, their delivery vehicles for a person with the right to carry out foreign economic activity and in respect of which export clearance has been established. Non-return to the territory of the Russian Federation of objects of the artistic, historical, and archaeological heritage of the peoples of the Russian Federation and foreign countries (Article 190 of the Criminal Code of the Russian Federation). The direct object is the relations and interests of the state regarding the possession and disposal of objects of the artistic, historical, and archaeological heritage of the peoples of the Russian Federation and foreign countries, as well as the preservation of the cultural heritage of the peoples of Russia. The objective side of the crime is expressed in the commission of action in the form of inaction. It consists in non-fulfillment of the obligations assigned to a particular person to return values that constitute the artistic, historical, and archaeological heritage of the peoples of the Russian Federation and foreign countries to the territory of the Russian Federation within a specified time. Non-return of funds in foreign currency from abroad (Article 193 of the Criminal Code of the Russian Federation). The direct object is the economic and financial interests of the Russian Federation. The subject of the crime is foreign currency, i.e banknotes, treasury bills, coins in circulation and being legal payment means in the corresponding foreign state or group of states, as well as banknotes withdrawn and being withdrawn from circulation but subject to exchange; funds in accounts in monetary units of foreign states and international monetary or settlement units.

\section{DISCUSSING THE RESULTS}

In addition, crimes are often committed encroaching on social relations that develop with regard to the calculation and payment of taxes and other fees. Evasion of payment of customs duties levied on a legal entity or an individual (Article 194 of the Criminal Code of the Russian Federation). The direct object is the economic and financial interests of the Russian Federation. The subject of the crime is customs payments. The objective side is characterized by an action in the form of inaction and consists of evading the payment of any customs duties levied on legal entities or individuals that constitute the subject of this crime in a large amount [5]. Concealment of funds or property of a legal entity or individual entrepreneur, at the expense of which taxes and/or fees should be collected (Article 199.2 of the Criminal Code of the Russian Federation). The direct object is the economic and financial interests of the state. The subject is cash or property of a legal entity or an individual entrepreneur in a large amount, at the expense of which the arrears of taxes and/or fees should be collected in accordance with the legislation of the Russian Federation on taxes and fees [8]. The objective side is characterized by an action in the form 
of concealment of cash or property of a legal entity or an individual entrepreneur, at the expense of which the arrears of taxes should be collected, committed in a large amount. Moreover, crimes are most often committed encroaching on public relations, interests ensuring bankruptcy

Illegal actions in bankruptcy (Article 195 of the Criminal Code of the Russian Federation). The direct object is the relations and legitimate interests of participants in economic activity, individual entrepreneurs and commercial organizations operating in the course of the bankruptcy procedure [23]. The subject of the crime under Article 195 of the Criminal Code includes property, property obligations, information on the property, accounting and other documents reflecting the economic activity of the enterprise [6]. The objective side is very complex and includes several mandatory signs: an action committed in various forms; consequences in the form of heavy damage to counterparts; a causal relationship between the action and the consequences; situation proving bankruptcy. Intentional bankruptcy (Article 196 of the Criminal Code). The direct object is the relations and legitimate interests of participants in economic activity, individual entrepreneurs and commercial organizations that are harmed in carrying out intentional bankruptcy. The subject of the crime is monetary obligations and obligatory payments. The objective side is characterized by action, consequences in the form of heavy damage and a causal relationship between them [7]. The subjective side is characterized by an intentional form of guilt. In this case, the legislator identifies the motive as a mandatory subjective attribute. The guilty acts in the personal interest or in the interests of other persons. Fake bankruptcy (Article 197 of the Criminal Code of the Russian Federation). The direct object is the interests of the state in the field of activity of state bodies authorized to organize work with bankrupt enterprises. The objective side characterizes the material components of the crime in its structure. The subjective side is characterized by guilt in the form of direct intention.

\section{CONCLUSIONS}

Crimes in the field of economic activity is a deliberate socially dangerous action stipulated by criminal law, encroaching on public relations in the sphere of production, distribution, exchange, and consumption of material goods and services. At present, Chapter 22 defines the signs of crimes that impede the establishment and normal functioning of the system of economic relations within the framework of a market economy based on all forms of ownership under state regulation. The previously used term "economic crimes" is now unacceptable since it does not cover the content of the provisions included in Chapter 22 of the Criminal Code because some of them provide for responsibility for tax and currency crimes, as well as for crimes committed in the field of customs relations, which are not related to economic activity but form a part of economic relations.
All provisions (except for Article 175 of the Criminal Code) are blanket in nature, for their clarification, it is required to refer to civil, tax, currency laws, and other regulatory acts that regulate economic activity, which give the concepts used in the provisions of Chapter 22 of the Criminal Code. While maintaining the generally accepted approach to the classification of objects into generic objects, specific objects, and direct objects, direct objects can be distinguished. They are specific social relations that are formed in the process of implementing a certain field of entrepreneurial and other economic activities. Some provisions indicate an additional object, the rights and freedoms of citizens as participants in economic relations. The objective side of crimes in the field of business and other economic activities is characterized mainly by actions. Some crimes can be committed only by inaction. Individual crimes can be committed both by action and inaction. A mandatory sign of the objective side of certain crimes is the socially dangerous consequences indicated in the dispositions of criminal law provisions in the form of heavy or especially heavy damage (Part 1 of Article 171 and Article 172, Article 173, Parts 1 and 2 of Article 176 of the Criminal Code, etc.). Components, in which the objective side includes socially dangerous consequences in the form of heavy and especially heavy damage, are called material ones. Crimes with such components are recognized to be completed from the moment of the actual onset of these socially dangerous consequences. Components, which do not contain signs related to the characterization of socially dangerous consequences, are formal. Often, the objective side of such crimes includes additional signs in the form of a large or especially large amount of the action, income, or debt. In most cases, these concepts are defined in the note to Article 169 of the Criminal Code, as well as the extent of the damage. But in some cases, they are revealed in the notes to specific articles. The subjective side of crimes in the field of economic activity is characterized by guilt in the form of intention. Some components contain additional signs of the subjective side, i.e the motive and the purpose. The subject of the crime in the field of economic activity may be an individual, which is sane and 16 years of age. It should be taken into account that the subjects of these crimes can be both general and special subjects. Sometimes, a special subject is not directly specified in the provision of the Criminal Code but this follows from the meaning of the law. The law establishes enhanced responsibility for committing crimes under aggravating and especially aggravating circumstances relating to the characterization of all elements of components of the crimes. Most of the aggravating and especially aggravating circumstances refer to the characteristic of the objective side of the crime, i.e. large and especially large amount, commission of a crime by a group of persons by prior conspiracy or by an organized group; using official position, using violence. In one case, an aggravating circumstance relating to the characteristic of the subjective side, self-interest, is Specified (Part 3 of Article 183 of the Criminal Code). 


\section{REFERENCES}

[1] Konstituciya Rossijskoj Federacii: [prinyata vsenarodnym golosovaniem 12.12.1993] // Sobranie zakonodatel'stva RF. - 2014, No. 31, st. 4398.

[2] Ugolovnyj kodeks Rossijskoj Federacii: [prinyat Gos. Dumoj 24 maya 1996 g.: odobren Sovetom Federacii 05 iyunya 1996 g.] // Sobranie zakonodatel'stva RF. - 1996. - No. 25. - St. 2954.

[3] Polyanina A.V. Osnovnye tendencii razvitiya ugolovnoj otvetstvennosti za nezakonnoe predprinimatel'stvo v Rossii// Obshchestvo i pravo. 2014. - No. 1. -S. 23-27.

[4] Pashinceva U. V. Harakteristika predprinimatel'stva kak prestupleniya, posyagayushchee na bankovskoe kreditovanie // Rossijskij sledovatel'. - 2012. - No. 3. S. 17.

[5] Gir'ko A.S. Ponyatie ekonomicheskoj kontrabandy, ee uroven' i dinamika // Rossijskij sledovatel'. - 2017. No. 3.- S. 2-8.

[6] Sitnikova A. Kontrabanda kak okonchennoe prestuplenie // Tamozhennoe delo. - 2018. - No. 4. - S. $45-48$.

[7] Kastrikina T. Vzaimodejstvie mezhdunarodnogo i nacional'nogo zakonodatel'stva $\mathrm{v}$ bor'be $\mathrm{s}$ tamozhennymi prestupleniyami // Tamozhennoe delo. 2015. - No. 1. - S. 41-46.

[8] SHaguch B. Sub"ekt nepravomernyh dejstvij pri bankrotstve i voprosy kvalifikacii // Obshchestvo i pravo. - 2016. - No. 3. - S. 5.

[9] Lemyagov N. Ob ob"ekte nepravomernyh dejstvij pri bankrotstve // Rossijskij sledovatel'. - 2013. No. 21. - S. 23.

[10] Muradov E. Rukovoditel' organizacii kak special'nyj sub"ekt prestuplenij v sfere ekonomicheskoj deyatel'nosti // Ugolovnoe pravo. - 2009. - No. 2. 